\title{
FAKTOR-FAKTOR PENENTU KEBAHAGIAAN SESUAI DENGAN KEARIFAN LOKAL DI BALI
}

\author{
${ }^{1}$ Gde Bagus Brahma Putra; ${ }^{2}$ I Ketut Sudibia \\ ${ }^{1}$ Fakultas Ekonomi Universitas Mahasaraswati Denpasar \\ ${ }^{2}$ Fakultas Ekonomi Universitas Udayana Denpasar \\ ${ }^{1}$ Email : brahmaputra@unmas.ac.id
}

\begin{abstract}
Abstrak
Kebahagiaan merupakan salah satu perkembangan baru dalam ilmu ekonomi. Maka dari itu, ilmu ekonomi seharusnya berbicara banyak tentang kebahagiaan individu. Artikel ini membahas mengenai faktor - faktor yang menentukan kebahagiaan individu sesuai dengan kearifan lokal di Bali. Faktor yang diidentifikasi dalam mempengaruhi kebahagiaan seseorang meliputi penghasilan, harapan, hubungan, iman, perilaku syukur, perilaku pro lingkungan, kesehatan, gender, modal sosial dan budaya.
\end{abstract}

Kata Kunci : Kebahagiaan, Kearifan Lokal, Ilmu Ekonomi

\begin{abstract}
Happiness is one of the new developments in economics. Therefore, economics should talk a lot about individual happiness. This article discusses the factors that determine individual happiness in accordance with local wisdom in Bali. Factors identified in influencing a person's happiness include income, expectations, relationships, faith, gratitude behavior, pro-environment behavior, health, gender, social and cultural capital.
\end{abstract}

Keywords: Happiness, Local Wisdom, Economics 


\section{Gde Bagus Brahma Putra dan I Ketut Sudibia. Faktor- Faktor Penentu ...}

\section{Pendahuluan}

Ilmu ekonomi saat ini berada pada tahapan evolusi yang menarik, saat dimana dimulai perpaduan dengan disiplin ilmu lainnya. Dalam perpaduan tersebut, ilmu psikologi merupakan disiplin yang paling dekat dengan ilmu ekonomi dibandingkan dengan disiplin lainnya. Hal ini memperkaya khasanah untuk memperluas asumsi ekonomi dan mengkatalisasi bidang perilaku yang berkembang dalam ilmu ekonomi. Pada dasarnya ilmu psikologi telah mendorong para ekonom untuk mengenali heterogenitas perilaku manusia.

Dibawah asumsi ekonomi yang konvensional, manusia dianggap menjadi sangat rasional, termotivasi oleh kepentingan pribadi, sibuk memaksimalkan utilitas pribadi, didorong oleh perhitungan ekonomi tanpa kepedulian oleh orang lain, mampu belajar seketika dan seterusnya. Namun pada kenyataannya, manusia dalam kehidupan nyata menghadapi masalah ekonomi secara lebih kompleks. Manusia tidak hanya didorong oleh kepentingan pribadi tetapi juga oleh altruisme, rasa bersalah, kebahagiaan, dan emosi lainnya. Dengan kata lain, pengenalan psikologi ke dalam perilaku ekonomi menyediakan alat untuk 'menantang' pusat asumsi ekonomi konvensional.

Kebahagiaan merupakan salah satu perkembangan baru dalam ilmu ekonomi. Frey (2008) menyatakan bahwa kebahagiaan menjadi salah satu masalah terpenting dalam kehidupan. Pencapaian kebahagiaan merupakan determinan terpenting dalam perilaku manusia. Maka dari itu, ilmu ekonomi seharusnya berbicara banyak tentang kebahagiaan individu.

Gagasan bahwa kebahagiaan adalah pusat dari kehidupan manusia telah ada sejak zaman dahulu. Filsuf Yunani Aristippus pada Abad ke - 4 SM berpendapat bahwa tujuan hidup adalah untuk memaksimalkan totalitas kesenangan seseorang. Sejak itu, kebahagiaan menjadi konsep yang diperdebatkan dalam psikologi dan lebih dari itu kebahagiaan juga bergerak ke ranah ilmu politik dan ilmu ekonomi. Jika memaksimalkan kebahagiaan adalah poin dalam kehidupan seseorang, maka seharusnya sistem pemerintahan dan ekonomi harus memaksimalkan kebahagiaan masyarakat secara agregat. Kondisi tersebut merupakan bentuk murni dari doktrin utilitarianisme yang diperkenalkan oleh Jeremy Bentham (1748 - 1832).

Kebahagiaan dianggap oleh banyak orang sebagai tujuan akhir dalam hidup dan memang pada kenyataannya setiap orang menginginkan kebahagiaan (Frey dan Stutzer, 2002). Deklarasi kemerdekaan di Amerika Serikat secara nyata menyatakan 'The Pursuit of Happiness' sebagai hak yang abadi sejalan dengan kehidupan dan kebebasan. Di sisi lain, Bhutan adalah negara pertama di dunia yang mengadopsi Gross National Happiness. Indikator Gross National Happiness meliputi 9 domain, yaitu kesehatan psikologis, kesehatan, pendidikan, penggunaan waktu, keanekaragaman dan ketahanan budaya, pemerintahan yang baik, vitalitas masyarakat, keanekaragaman dan ketahanan ekologis, dan standar hidup. Konsep Gross National Happiness diperkenalkan oleh pemimpin Bhutan sebagai sarana untuk menempatkan prinsip spiritual Budha keadalam jantung kehidupan ekonomi. 
Sejarah kebahagiaan bukanlah sejarah biasa dan subyeknya juga tidak biasa. Gagasan tentang kebahagiaan mengarahkan kita pada penilaian kondisi seseorang secara menyeluruh. Hal tersebut mendorong analisis dalam kebahagiaan untuk mempertimbangkan semua pertimbangan tentang apa yang diinginkan dan berharga oleh individu. Walaupun tampaknya kebahagiaan sangatlah luas, namun tetap diperlukan batasan dalam menentukan sebuah corak dan pola kebahagiaan.

Perkembangan pemikiran internasional mengenai kebahagiaan juga telah diadopsi di Indonesia. Indonesia berada pada urutan ke-81 dari 155 negara jika kita berbicara mengenai kebahagiaan negara - negara di dunia (World Happiness Report, 2017). Badan Pusat Statistik Indonesia mempublikasikan bahwa indeks kebahagiaan di Indonesia tahun 2017 berdasarkan hasil Survey Pengukuran Tingkat Kebahagiaan (SPTK) sebesar 70,69 pada skala 0 sampai dengan 100. Kebahagiaan tersusun oleh tiga dimensi, yaitu kepuasan hidup (life satisfaction), perasaan (affective) dan makna hidup (eudaimonia). Jika dibandingkan provinsi lainnya di Indonesia, Bali berada pada peringkat 9 secara nasional. Kebahagiaan mencakup fenomena kehidupan yang kompleks dan berbagai determinannya saling berkorelasi.

Berbagai tujuan, kesenangan, keinginan, dan penilaian tentang apa yang berharga dan sebagainya biasanya diambil dan dimasukkan dalam menganalisis kebahagiaan, namun tampaknya sering bertentangan satu sama lain sehingga tidak dapat disurvei dan dievaluasi secara bersama (White, 2006). Jika kebahagiaan adalah sikap terhadap hidup kita, kita harus segera memastikan bahwa itu adalah hal mendasar yang meliputi segudang sikap positif terhadap orang, hubungan, kegiatan, dan komponen lain dari kehidupan kita (Martin, 2012). Artikel ini membahas mengenai faktor - faktor yang menentukan kebahagiaan individu sesuai dengan kearifan lokal di Bali.

\section{Metodologi}

Artikel ini menggunakan metode penelitian kualitatif berupa penelusuran dokumen mengenai materi yang terkait dalam artikel.

\section{Pembahasan}

Ide bahwa seseorang mendambakan kebahagiaan sebagai tujuan terakhir mereka dalam hidup tidak terbantahkan. Di satu sisi, para pemikir liberal seakan kurang sejalan, mereka berpendapat bahwa kebebasan jauh lebih penting dibandingkan kebahagiaan. Kemungkinan juga seseorang harus punya pilihan untuk tidak bahagia. Hal ini bisa dilihat sebagai rasa kurang puas dari seseorang dan tetap berusaha untuk mendapatkan lebih. Dari sisi tersebut, ketidakbahagiaan itu dipandang sebagai hal yang produktif.

Kebahagiaan bukanlah tujuan yang statis dimana seseorang mampu untuk mencapai dengan mencita - citakannya. Sebaliknya, kebahagiaan adalah proses dari kehidupan yang baik (eudaimonia) yang menghasilkan kepuasan jangka panjang. Bagi individu yang mencoba mendapatkan kebahagiaan dengan perilaku tertentu biasanya tidak akan mencapai kebahagiaan yang berkelanjutan. Teori evolusi mengingatkan kita 


\section{Gde Bagus Brahma Putra dan I Ketut Sudibia. Faktor- Faktor Penentu ...}

bahwa manusia tidak berkembang untuk bahagia, namun untuk bertahan hidup dan bereproduksi (Camerer, 2007).

Penghargaan subyektif terhadap kehidupan kita secara keseluruhan dinamakan kepuasan hidup, sinonimnya adalah kesejahteraan subyektif atau kebahagiaan (Veenhoven, 2015). Definisi kebahagiaan diklasifikasi oleh Veenhoven (2006) menjadi definisi afektif, definisi kognitif, definisi sikap dan definisi campuran. Definisi afektif menghubungkan kebahagiaan dengan keadaan emosi tertentu. Definisi kognitif menekankan kepada evaluasi kehidupan yang dilakukan oleh individu terhadap keseluruhan hidupnya. Definisi sikap menekankan bagaimana individu melakukan penyesuaian sikap selama hidupnya. Definisi campuran menggabungkan beberapa elemen dalam kebahagiaan. Diener et. al., (2003) menyebutkan beberapa karakteristik utama dalam kebahagiaan, yaitu kebahagiaan mengacu kepada perspektif individu itu sendiri, kebahagiaan merupakan aspek negatif dan positif dari kehidupan seseorang dan kebahagiaan menitikberatkan pada evaluasi dari kehidupan seseorang secara utuh.

Nettle (2005) menjelaskan bahwa menjadi mungkin tidak selalu menjadi keadaan yang absolut, tetapi mengandung perbandingan implisit dengan harapan atau dengan apa yang orang lain miliki. Selanjutnya Nettle (2005) mengklasifikasikan tiga tingkat kebahagiaan, yaitu tingkat satu merupakan 'momentary feelings', tingkat dua berupa 'judgement about feelings' dan tingkat tiga adalah 'quality of life'. Momentary feelings dikatakan sebagai perasaan sementara atas suatu fenomena khusus. Judgement about feelings adalah dimana saat orang mengatakan bahwa mereka bahagia dengan hidup mereka, namun bukan berarti mereka mengalami kesenangan sepanjang waktu. Hal ini merupakan kebahagiaan yang dipelajari oleh para psikolog. Terakhir quality of life disebutkan sebagai tahapan dimana kebahagiaan tidak memiliki karakteristik fenomena karena bukan keadaan emosional.

Dalam meneliti kebahagiaan, metode penelitian ekometrik dan eksperimental menggunakan indikator yang dapat menginformasikan tentang konsep utilitas dalam ilmu ekonomi dengan lebih banyak konten psikologis. Hal ini menunjukkan bahwa pemahaman tentang utilitas individu sangat dekat dengan kebahagiaan seseorang. Beberapa penelitian memberikan kontribusi yang sangat berarti dalam kebahagiaan, seperti yang dilakukan oleh Bruno S. Frey, Alois Stutzer, Daniel Kahneman dan Richard Easterlin.

Kebahagiaan juga muncul sebagai prediksi dan penguji teori ekonomi. Beberapa teori mencoba memperhitungkan pasokan tenaga kerja dan pengangguran dalam siklus bisnis. Dalam ekonomi makro neoklasik dimana pasar tenaga kerja diasumsikan dalam keadaan yang sempurna, seseorang diasumsikan melakukan penyesuaian penawaran tenaga kerja sebagai tanggapan terhadap perubahan upah dan tingkat bunga. Jika mereka menganggur, hal tersebut dilakukan secara sukarela. Menurut pandangan ini, hilangnya penghasilan karena pengangguran dipilih secara sukarela dan penganggur tidak kehilangan utilitasnya. Sebaliknya, dalam ekonomi makro neo keynesian mengaitkan pengangguran yang tidak disengaja dengan harga dan kompleksitas upah. Orang yang menganggur akan bersedia menerima pekerjaan 
pada tingkat upah saat ini, tetapi tidak dapat menemukannya dan kehilangan utilitas jika mereka kehilangan pekerjaan mereka (Frey, 2008).

Stutzer dan Lalive (2004) menyatakan norma sosial mempengaruhi perilaku seseorang yang menganggur. Semakin kuat norma sosial (etos kerja) yang dimiliki dalam suatu masyarakat otomatis mengurangi durasi menganggur seseorang dalam masyarakat tersebut. Hal ini memiliki dua kemungkinan, apakah norma sosial lebih cenderung menghasilkan sanksi sosial atau apakah mendorong seseorang yang menganggur untuk memperoleh informasi pekerjaan secara lebih cepat.

Gruber and Mullainathan (2005) menawarkan model ekonomi yang dapat membuat prediksi berbeda tentang pengaruh pajak cukai terhadap utilitas seseorang, meskipun cenderung diramalkan hal tersebut mengurangi konsumsi seseorang ketika barang dikenakan pajak. Biasanya diasumsikan bahwa orang akan menentang pengenaan pajak atas barang yang mereka konsumsi, karena mereka kehilangan utilitas. Contoh yang paling nyata adalah masyarakat perokok di Amerika Serikat dan Kanada, kenaikan pajak cukai rokok membantu mereka mengurangi kebiasaan buruk. Hal tersebut memungkinkan kita untuk mempelajari bagaimana pajak berpengaruh terhadap kebahagiaan seseorang.

\subsection{Penghasilan dan Kebahagiaan}

Orang dengan pendapatan yang lebih tinggi memiliki lebih banyak peluang untuk mencapai apa pun yang mereka inginkan, khususnya mereka dapat membeli lebih banyak barang dan jasa. Selain itu, mereka juga memiliki status yang lebih tinggi di masyarakat. Gagasan hubungan antara penghasilan dan kebahagiaan pada waktu dan negara tertentu telah menjadi subyek literatur empiris yang besar. Sebagai hasil penelitian yang kuat dan diterima secara umum, telah ditemukan bahwa orang-orang kaya rata-rata melaporkan tingkat kebahagiaan yang lebih tinggi (Blanchflower dan Oswald, 2004a, 2004b; Easterlin 1995, 2001; Di Tella dan MacCulloch, 2006; Frey and Stutzer, 2000).

Hubungan antara pendapatan dan kebahagiaan, baik dalam perhitungan regresi sederhana dan ketika sejumlah besar faktor-faktor lain digunakan dalam multiple regressions terbukti secara statistik sangat signifikan. Hal ini berarti pendapatan 'membeli kebahagiaan'. Penghasilan yang lebih tinggi mungkin menyebabkan orang lebih bahagia dan orang yang lebih bahagia juga dapat menghasilkan pendapatan yang lebih tinggi. Gardner dan Oswald (2001) menemukan bahwa pemenang lotere di Inggris sebesar $£ 50.000$ mengungkapkan kebahagiaan yang lebih tinggi dengan standar deviasi antara 0,1 sampai 0,3. Hal tersebut menunjukkan bahwa pendapatan yang lebih tinggi memang menyebabkan orang menjadi lebih bahagia.

Ada banyak proses yang dapat menjelaskan mengapa penghasilan lebih tinggi tidak memiliki lebih banyak efek pada kebahagiaan. Hal yang paling penting adalah bahwa individu beradaptasi dengan standar hidup baru mereka dan mereka membandingkan diri mereka dengan orang lain. Kondisi tersebut oleh Chang (2012) disebut dengan pendapatan relatif. Manusia tidak mampu dan tidak mau membuat penilaian mutlak. Sebaliknya, mereka terus-menerus menarik perbandingan dari lingkungan mereka, dari masa lalu, atau dari harapan masa depan mereka. Jadi, orang- 


\section{Gde Bagus Brahma Putra dan I Ketut Sudibia. Faktor- Faktor Penentu ...}

orang memperhatikan dan bereaksi terhadap penyimpangan dari tingkat aspirasi (Smith, et. al, 1989).

Sebagian orang khawatir tentang posisi mereka dalam tingkat pendapatan. Hal ini bukan karena pentingnya tingkat pendapatan, namun posisi seseorang relatif terhadap individu yang lain. Masalah posisional bukan aspek baru dari sifat manusia, tetapi sifat tersebut mungkin semakin menonjol saat ini untuk suatu perbandingan sosial. Sejak dahulu, banyak ekonom menekankan bahwa individu membandingkan diri mereka dengan orang lain yang signifikan sehubungan dengan pendapatan, konsumsi, status dan utilitas. Veblen (1899) mengatakan istilah tersebut sebagai 'conspicuous consumption'.

Falk dan Knell (2004) menjelaskan bawah ketika membuat perbandingan orang - orang melihat ke atas, tidak ke bawah. Hal tersebut cenderung mendorong seseorang untuk mencapai tingkatan yang lebih tinggi. Maka dari itu, semakin tinggi referensi perbandingan pendapatan suatu kelompok, semakin sedikit orang yang puas dengan pekerjaan yang mereka miliki. Perbandingan sosial juga dapat terjadi dalam keluarga (Neumark dan Postlewaite, 1998).

Individu juga membiasakan diri dengan penghasilan atau tingkat konsumsi yang baru. Tambahan barang dan jasa pada awalnya memberikan kebahagiaan ekstra, tetapi biasanya hanya sementara. Proses atau mekanisme yang mengurangi efek hedonis dari suatu stimulus konstan atau berulang disebut dengan adaptasi.

\subsection{Harapan dan Kebahagiaan}

Belliotti (2004) menjelaskan menjadi sangat kompetitif dan perfeksionis adalah strategi yang buruk untuk kebahagiaan. Orang-orang yang bahagia menemukan caracara untuk menata kegagalan mereka yang tampak sebagai peristiwa-peristiwa terpisah yang tidak mendefinisikan identitas mereka. Orang yang tidak bahagia terobsesi dengan kegagalan, menganggap hal itu akan terus berlanjut dan mendefinisikan diri mereka sendiri melalui kekecewaan mereka.

Dengan cara menyesuaikan harapan kita, kita meningkatkan kecenderungan untuk bahagia. Jika kita menilai saat ini dan memabandingkannya dengan hari besar dalam hidup kita, maka kita akan merasa frustrasi. Jika kita menilai saat ini dan membandingkannya dengan peristiwa tragis dalam hidup kita, kita dapat memupuk suatu penghargaan. Perbedaan antara orang yang bahagia dan tidak bahagia adalah kurangnya fungsi keseimbangan kumulatif positif secara objektif atas momen negatif yang mereka alami masing-masing.

Lebih lanjut Belliotti (2004) menjelaskan bagaimana kita mempersepsikan dan menginterpretasikan penyebab dan konsekuensi dari suatu kejadian dalam hidup adalah suatu hal yang penting. Hal tersebut memberi kekuatan kebahagiaan kepada seseorang. Bukan hanya harapan kita yang penting untuk kebahagiaan, tetapi juga kenangan. Kita dapat memilih untuk merenungkan tentang peristiwa masa lalu yang membuat kita kesal seperti ketidakadilan di kantor, orang-orang yang telah menghina kita, ketidakadilan, pelanggaran hierarkis, serta keluarga dan teman yang telah mengkhianati kepercayaan kita. Jika begitu, kita cenderung menumbuhkan ketidakbahagiaan oleh subyek yang kita huni. Dengan berkonsentrasi pada peristiwa 
saat ini dan masa lalu yang kita nikmati, maka kita telah meningkatkan prospek kebahagiaan diri.

\subsection{Hubungan dan Kebahagiaan}

Aristoteles menekankan bahwa manusia adalah mahluk sosial. Jika manusia hidup untuk waktu yang lama dalam kesendirian, maka dia adalah dewa atau binatang bukan manusia. Belliotti (2004) mengungkapkan meskipun kita memerlukan kesendirian, rasa yang tajam dari individualitas, keunikan, keistimewaan, dan kemandirian individu juga membutuhkan ukuran komunitas. Manusia mencari ikatan, koneksi dan memperluas subjektivitas melalui keluarga, teman, dan kekasih. Seseorang perlu memperluas lingkup kepedulian terhadap orang lain dan merasakan bahwa orang lain juga memiliki kepedulian terhadap individu lainnya. Keintiman, berbagi, dan kepemilikan sosial adalah bahan terpenting untuk kebahagiaan.

Para ilmuwan sosial memperkirakan bahwa sekitar 70 persen kebahagiaan individu bergantung pada jumlah dan kualitas persahabatan, kedekatan keluarga, dan kesehatan hubungan dengan tetangga dan rekan kerja. Dukungan sosial, rasa saling menghargai, dan kemampuan untuk berbagi sangat penting untuk kebahagiaan. Hal tersebut sangat tergantung dan bisa dipelihara melalui komunikasi. Memberi tahu orang lain bahwa mereka penting bagi kita dapat memperdalam ikatan timbal balik. Berbagi masalah dengan orang-orang terdekat dapat meringankan tekanan dari suatu masalah.

\subsection{Iman dan Kebahagiaan}

Seseorang dengan keyakinan spiritual yan kuat lebih bahagia daripada mereka yang tidak memiliki keyakinan tersebut. Keyakinan agama, mitos, dan ritual yang menopang mereka menawarkan makna, rasa keteraturan dan jawaban atas dasar pertanyaan hidup seperti siapa saya ?; apa takdirku ?; kenapa saya disini ?; bagaimana seharusnya saya hidup ?; apa artinya semua ini ?. Orang yang memiliki iman pasti memiliki jawaban dibandingkan dengan orang yang tidak beriman (Belliotti, 2004).

Keyakinan agama yang sederhana dan kuat menghubungkan seseorang dengan kekuatan hidup. Iman memberi menguatkan manusia dan menenangkan keraguan di waktu yang baik dan buruk. Tetapi iman agama tidak bisa disimulasikan, kita tidak bisa begitu saja mengadopsinya sebagai strategi setelah menganalisis temuan survei terbaru tentang kebahagiaan. Keyakinan agama memang didasarkan pada komitmen spiritual, bukan pada tindakan. Namun, tidak semua iman itu religius. Percaya pada diri sendiri, menerima diri kita sendiri apa adanya dan sangat berkomitmen untuk tindakan yang baik untuk diri dapat memupuk kebahagiaan.

\subsection{Bersyukur dan Kebahagiaan}

Bersyukur berasal dari Bahasa Latin 'gratia' yang berarti bersyukur dan berkaitan dengan kebaikan dan keindahan memberi dan menerima. Secara historis, rasa syukur telah dipandang sebagai beragam kebajikan sosial dan kemasyarakatan, motivator kebajikan dan pengingat kognitif dan emosional akan kebutuhan sosial untuk melakukan timbal balik (Emmons dan McCullough, 2003). Aliran psikologi positif secara khusus menekankan bahwa rasa syukur semakin dipahami sebagai adaptasi evolusioner atau metode pertukaran sosial. Rasa syukur dapat dicirikan baik sebagai 


\section{Gde Bagus Brahma Putra dan I Ketut Sudibia. Faktor- Faktor Penentu ...}

konsep moral dan sosial yang ekspresinya memiliki implikasi potensial untuk kepuasan dan kesejahteraan hidup. Sebagai sebuah konsep, bersyukur memiliki kajian yang luas dan abadi.

Emmons dan McCullough (2003) menyatakan bahwa rasa syukur berasal dari pengakuan akan hasil positif yang dihasilkan oleh orang lain, dengan perilaku yang disengaja, menanggung biaya untuk mereka dan memberi nilai bagi penerimanya. Rasa syukur difokuskan untuk kesejahteraan dan kepuasan hidup. Syukur juga bisa dilihat sebagai perilaku prososial yang dihasilkan dari perilaku moral dalam hal manfaat yang diberikan dan diterima. Hal yang lebih khusus lagi adalah rasa syukur bertindak sebagai 'barometer moral', motif dan penguat (McCullough et. al., 2001).

Rasa syukur dapat dilihat sebagai perberlakuan norma sosial atau sekedar pelestarian diri, karena tidak memiliki rasa syukur secara umum akan dicemooh dan akan mencegah perilaku serupa pada masa yang akan datang (Emmons dan Shelton, 2002). Selain itu, mungkin saja pengalaman bersyukur bersekutu dengan kesadaran akan apa yang terutang sebagai konsekuensinya dan hal inilah yang mendorong perilaku bersyukur, bukan rasa syukur. Bersyukur bisa mengubah sifat atau kemajuan faktor lain, misalnya lingkungan atau emosional seseorang. Hal yang paling penting adalah syukur bisa menjadi kunci dalam hal dukungan sosial yang dirasakan atas dasar perilaku dan pemahaman atas perilaku diri sendiri atau orang lain berdasarkan persepsi diri. Syukur memiliki relevansi yang tidak terbantahkan baik untuk pemahaman dan perkembangan kesejahteraan dan kepuasan hidup.

\subsection{Perilaku Pro Lingkungan dan Kebahagiaan}

Perilaku pro lingkungan adalah tindakan sadar yang dilakukan oleh individu sehingga dapat mengurangi dampak negatif aktivitas manusia terhadap manusia dan untuk meningkatkan kualitas lingkungan (Jensen, 2002). Konsep perilaku pro lingkungan menunjukkan beberapa aspek yang problematis, meliputi marginalisasi tindakan tidak langsung terhadap lingkungan, pembatasan tindakan dan perilaku terhadap individu dan asumsi bahwa masalah lingkungan yang sangat kompleks saat ini dapat ditangani melalui cara yang jelas.

Perilaku pro lingkungan telah didefinisikan sebagai sebuah tindakan, baik individu maupun kelompok yang diarahkan untuk memperbaiki masalah - masalah lingkungan (Sivek dan Hungerford, 1990). Sejalan, Axelrod dan Lehman (1993) juga mendefinisikan perilaku pro lingkungan sebagai tindakan yang mendukung pelestarian lingkungan atau konservasi. Perilaku pro lingkungan juga meminimalkan dampak negatif kepada alam yang dilakukan oleh individu (Kollmuss dan Agyeman, 2002).

Dalam tahun - tahun terakhir ini, para ekonom semakin menyadari betapa pentingnya dampak dari berbagai persoalan lingkungan hidup terhadap keberhasilan upaya pembangunan. Todaro dan Smith (2002), menyatakan bahwa lingkungan dan pembangunan merupakan permasalahan yang mendasar. Kehidupan dari setengah lebih jumlah penduduk yang aktif secara ekonomi di negara - negara berkembang sangat bergantung pada lingkungan melalui kegiatan pertanian dalam arti luas. Kualitas lingkungan memengaruhi dan dipengaruhi oleh pembangunan ekonomi. 
Coelho et. al. (2017) menyatakan bahwa perilaku pro lingkungan adalah bagian penting dari perubahan masyarakat menuju lebih baik di masa depan yang berkelanjutan. Memahami bagaimana kecenderungan seseorang untuk mengadopsi perilaku pro lingkungan adalah hal kompleks yang masih belum sepenuhnya dipahami. Sebenarnya, adopsi perilaku pro lingkungan cenderung menuntut individu, mengharuskan mereka menghabiskan waktu dan usaha kognitif yang lebih besar dalam merenungkan sumber daya ekonomi.

Dampak lingkungan dari individu pada lingkungan alam telah menyebabkan permasalahan ekologis, ekonomi dan perubahan sosial. Psikolog secara aktif telah mempelajari faktor - faktor yang terkait dengan perilaku konservasi, seperti kegiatan lingkungan, konsumerisme atau konservasi energi. Kaiser dan Wilson (2004) mendefinisikan perilaku ekologis sebagai perilaku pro sosial, pembuangan sampah ekologis, konservasi energi dan air, perilaku konsumen yang sadar secara ekologis, penanggulangan sampah, berpartisipasi secara sukarela dalam kegiatan perlindungan alam dan penggunaan mobil berbahan bakar ramah lingkungan.

Perilaku pro lingkungan adalah jenis perilaku pro sosial khusus, seperti perilaku yang diarahkan dan dilakukan dengan maksud mempromosikan kesejahteraan individu, kelompok atau organisasi. Gifford (2014) menyatakan bahwa banyak masalah lingkungan berakar pada perilaku manusia dan dapat diatasi dengan memahami perilaku pro lingkungan. Perilaku pro lingkungan termasuk dalam tindakan yang mendukung keberlanjutan, Corral-Verdugo et. al., (2011) menemukan bahwa tindakan tersebut berpengaruh positif terhadap kebahagiaan.

\subsection{Kesehatan dan Kebahagiaan}

Secara luas diakui bahwa faktor mental dan kesehatan psikologis dapat mempengaruhi fungsi fisik dan memiliki fungsi positif terhadap kesehatan fisik. Hal tersebut memiliki akar yang kuat dalam ilmu psikologi. Tekanan mental memberikan efek negatif terhadap kesehatan fisik dan berlaku sebaliknya (Zautra et. al., 2005). Dalam konteks ini biasanya diasumsikan bahwa kebahagiaan itu kondusif untuk kesehatan fisik.

Seedhouse (1996) menyatakan bahwa kebahagiaan dipercaya membantu menyembuhkan orang sakit dan melindungi orang sehat dalam melawan penyakit. Dalam pandangan ini, perawatan kesehatan seharusnya tidak hanya fokus terhadap penyakit, melainkan juga harus peduli dengan kualitas hidup yang lebih luas. Pandangan ini tercermin dalam definisi kesehatan yang luas dari Organisasi Kesehatan Dunia (WHO) yang meliputi kesehatan fisik, mental dan kesejahteraan sosial.

Veenhoven (2007) menyatakan bahwa kesehatan fisik dapat diukur secara obyektif menggunakan penilaian medis atau secara subyektif menggunakan selfreports. Jika mengukur kesehatan dengan menggunakan self-reports, akan ada peluang yang adil bahwa penilaian kesehatan itu membawa warna kebahagiaan itu sendiri. Orang yang bahagia hidup lebih lama, mungkin karena kebahagiaan mendukung kesehatan fisik.

\subsection{Gender dan Kebahagiaan}




\section{Gde Bagus Brahma Putra dan I Ketut Sudibia. Faktor- Faktor Penentu ...}

Hal penting yang harus diperhatikan dalam membicarakan kebahagiaan adalah memastikan apakah gender memainkan efek diskriminatif dalam membentuk pola kebahagiaan (Bruni, 2007). Hal ini didasarkan oleh beberapa pertimbangan, yaitu pertama pria dan wanita pada dasarnya berbeda secara biologis, psikologis dan budaya, berbeda secara emosional dan kognitif, cara memberikan makna pada kondisi dan peristiwa eksternal, serta berbeda dalam interaksi sosial sehingga membentuk pola kebahagiaan spesifik gender. Kedua, mulai zaman kontemporer setidaknya sejak awal abad ke - 20 terjadi kemajuan yang luar biasa dalam kondisi kehidupan perempuan mulai dari negara - negara barat, penaklukan hak - hak politik, meningkatnya partisipasi angkatan kerja perempuan, pencapaian status sosial yang lebih egaliter dan pertimbangan yang lebih baik untuk peran perempuan dalam masyarakat adalah contoh - contoh yang membuktikan secara tak terbantahkan untuk kondisi kualitas hidup yang lebih tinggi secara bertahap ditetapkan untuk perempuan.

\subsection{Modal Sosial dan Kebahagiaan}

Modal fisik umumnya mengacu pada bangunan dan peralatan yang digunakan untuk produksi barang dan jasa. Beberapa dekade yang lalu, para ekonom mulai berpikir lebih eksplisit tentang keterampilan dan pendidikan sebagai bentuk modal lain, yaitu modal manusia. Dewasa ini, para ilmuwan sosial di banyak negara telah mengamati bahwa jejaring sosial dan norma timbal balik serta kepercayaan yang terkait juga dapat memiliki efek yang kuat pada tingkat dan efisiensi produksi dan kesejahteraan. Istilah modal sosial telah digunakan untuk merujuk pada efek tersebut (Coleman, 1993; Haraka, 2002; OECD, 2001; dan Woolcock, 2001).

Inti ide dari modal sosial sangatlah sederhana dimana suatu jaringan sosial memiliki nilai. Modal sosial memiliki nilai kepada orang-orang dalam suatu jaringan. Modal sosial dapat diwujudkan dalam ikatan di antara keluarga, teman dan tetangga, lingkungan kerja, tempat ibadah, masyarakat, bahkan mungkin di 'komunitas virtual' berbasis internet. Meskipun tidak secara tegas memasukkan kepercayaan sosial dalam definisi inti modal sosial, norma timbal balik dan kepercayaan adalah kesamaan yang mirip dari suatu jaringan sosial. Kepercayaan sosial, yaitu keyakinan bahwa orang orang di sekitar kita dapat dipercaya adalah indeks empiris modal sosial yang kuat pada tingkat agregat.

Para pendukung pandangan modal sosial telah menyatakan korelasi yang kuat di berbagai negara antara jaringan sosial yang dinamis dan hasil sosial yang penting seperti tingkat kejahatan yang lebih rendah, peningkatan kesejahteraan anak, kesehatan masyarakat yang lebih baik, administrasi pemerintahan yang lebih efektif, mengurangi korupsi politik dan penghindaran pajak, meningkatkan kinerja pasar, dan kinerja pendidikan (Putnam et. al., 1993; Knack dan Keefer, 1997; Sampson et. al., 1997; Rubenson, 2000; Woolcock, 2001).

Modal sosial datang dalam berbagai bentuk dan tidak semuanya dapat dipertukarkan atau dipergunakan untuk tujuan yang sama. Demikian pula kita perlu membedakan antara berbagai jenis modal sosial, seperti perbedaan antara modal sosial yang bersifat 'ikatan' dan bersifat 'menjembatani'. Modal sosial yang bersifat sebagai suatu 'ikatan' merupakan hubungan antara orang-orang yang mirip dalam etnis, usia, 
kelas sosial, dan sejenisnya. Sedangkan modal sosial yang bersifat 'menjembatani' adalah tautan yang melintasi berbagai garis pembelahan sosial. Tetapi pada intinya adalah bahwa jejaring sosial dapat menjadi aset yang kuat, baik untuk individu maupun untuk masyarakat.

Modal sosial yang berperan dalam hubungan sosial, termasuk perkawinan dan tidak terbatas pada itu memberikan suatu korelasi yang paling kuat terhadap kebahagiaan. Orang-orang yang memiliki teman dekat dan orang kepercayaan, tetangga yang ramah dan rekan kerja yang mendukung cenderung tidak mengalami kesedihan, kesepian, harga diri rendah, dan masalah dengan makan dan tidur. Kebahagiaan paling baik diprediksi oleh luas dan kedalaman koneksi sosial seseorang. Bahkan, individu yang memiliki hubungan baik dengan anggota keluarga, teman atau pasangan adalah prasyarat untuk kebahagiaan mereka bahkan lebih dari sekadar uang atau ketenaran (Helliwell dan Putnam, 2004).

\subsection{Budaya dan Kebahagiaan}

Dalam psikologi, suatu emosi sering dilihat sebagai hal yang universal dan ditentukan secara biologis (Ekman, 1992). Saat ini, sejumlah psikolog yang berorientasi kepada budaya telah menekankan peran penting dari makna yang dikenal dalam suatu masyarakat (mitos dan pengetahuan) dan bentuk praktis dari suatu emosi (rutiitas harian) (Kitayama, 2002). Makna dan praktik tersebut merupakan wujud dari way of life lokal yang secara keseluruhan mendefinisikan budaya (Bruner, 1990).

Para ahli teori yang berorientasi budaya ini berpendapat bahwa emosi bukanlah hasil langsung dari mekanisme fisiologis atau neurologis. Sebaliknya, emosi selalu terletak dan tertanam dalam konteks budaya tertentu. Dengan demikian, suatu masyarakat sepenuhnya jenuh dengan makna budaya (Kitayama et. al., 2006). Analisis ini menyiratkan bahwa, makna kebahagiaan mungkin sangat bervariasi antar budaya (Kitayama dan Markus, 2000). Dengan demikian, orang - orang dalam budaya yang berbeda dapat mengkategorikan jenis peristiwa dan pengalaman positif yang sangat berbeda sebagai contoh kebahagiaan.

Setiap wilayah budaya memiliki ciri khas tersendiri. Misalnya, dalam budaya Eropa dan Amerika Utara terdapat keyakinan kuat mengenai kebebasan individu. Hal itu diyakini sebagai pusat pemikiran, tindakan dan motivasi. Dalam hal ini sebuah hubungan sosial memang penting, namun hubungan tersebut terbangun berdasarkan kemandirian masing - masing individu. Seseorang bebas memilih untuk memasuki suatu hubungan sosial. Selain itu, kebahagiaan itu sendiri sering ditafsirkan sebagai salah satu atribut internal yang harus dikejar dan dicapai melalui perjuangan pribadi. Dengan kata lain, kebahagiaan cenderung dibangun sebagai pencapaian pribadi (Uchida, et. al., 2004).

Sebaliknya, Uchida, et. al. (2004) menyatakan dalam budaya Asia Timur ada asumsi yang kontras tentang keterhubungan dan interdependensi diri dengan orang lain. Hubungan diri dengan orang lain diyakini sebagai pusat pemikiran, tindakan, dan motivasi. Batas simbolis antara diri dan individu lainnya dikaburkan dan terus dinegosiasikan melalui interaksi sosial. Individu pribadi cukup penting, namun interaksi dibangun sesuai dengan asumsi mendasar tentang interdependensi dari 


\section{Gde Bagus Brahma Putra dan I Ketut Sudibia. Faktor- Faktor Penentu ...}

individu yang terlibat. Ide tentang sifat manusia yang saling bergantung cukup luas dalam budaya Asia Timur. Selain itu ide - ide ini sering mendasari praktik, rutinitas sehari-hari, wacana dan lembaga sosial yang secara keseluruhan mendefinisikan realitas sosial dari konteks budaya ini.

Individu dalam konteks budaya Asia Timur sangat termotivasi untuk menyesuaikan diri dengan hubungan sosial yang bersangkutan. Komitmen terhadap peran sosial, kewajiban sosial, dan kesiapan untuk menanggapi harapan sosial adalah semua manifestasi dari motivasi berorientasi sosial untuk mewujudkan saling ketergantungan (Morling et. al., 2002). Hal ini menyiratkan bahwa kebahagiaan dalam budaya Asia Timur cenderung sangat tergantung pada realisasi hubungan sosial positif yang menjadi bagian dari diri.

Kebahagiaan pribadi sering merusak hubungan sosial. Misalnya, menekankan keberhasilan diri dapat menyebabkan kecemburuan dan iri hati orang lain. Bentuk kebahagiaan pribadi semacam itu sering dianggap tercemar dan tidak lengkap, maka sebagai konsekuensinya tidak ada keinginan kuat untuk mengejar kebahagiaan pribadi dengan mengorbankan keharmonisan sosial. Sebaliknya, kebahagiaan dipandang sebagai keadaan antar individu yang didasarkan pada simpati, belas kasih, dan dukungan bersama. Singkatnya, kebahagiaan dibangun sebagai realisasi harmoni sosial (Kitayama dan Markus, 2000).

\section{Penutup}

Berbagai macam faktor menentukan kebahagiaan individu. Dalam makalah ini, faktor - faktor yang diidentifikasi dalam mempengaruhi kebahagiaan seseorang meliputi penghasilan, harapan, hubungan, iman, perilaku syukur, perilaku pro lingkungan, kesehatan, gender, modal sosial dan budaya. Beberapa faktor tersebut dikemukakan dengan menyesuaikan dengan kearifan lokal yang ada di Bali. Kebahagiaan memang memiliki ranah yang sangat luas, maka dari itu diperlukan batasan - batasan dalam mendefinisikan kebahagiaan itu sendiri.

\section{REFERENSI}

Axelrod, Lawrence J. dan Darrin R. Lehman. 1993. Responding to Environmental Concern: What Factors Guide Individual Action ?. Journal of Environmental Prychology. Academic Press Ltd.

Bellioti, Raymond Angelo. 2004. Happiness is Overated. Rowman \& Littlefield Publishers Inc: USA.

Blanchflower, David dan Andrew Oswald. 2004a. Money, Sex and Happiness: An Empirical Study. Scandinavian Journal of Economics 106: 393-415.

Blanchflower, David dan Andrew Oswald. 2004b. Well-Being Over Time in Britain and The USA. Journal of Public Economics 88: 1359-1386.

Bruner, Jerome. 1990. Acts of Meaning. Harvard University Press: Cambridge. 
Bruni, Luigino. 2007. The 'Technology of Happiness' and The Tradition of Economic Science. Dalam Handbook on The Economics of Happiness by Luigino Bruni and Pier Luigi Porta (Eds.). Edward Elgar Publishing Limited: UK.

Camerer, Colin. 2007. Neuroeconomics: Using Neuroscience to Make Economic Predictions. Economic Journal 117: C26-C42.

Chang, Wen-Chun. 2012. Climbing Up The Social Ladders : Identity, Relative Income, and Subjective Well-being. Springer Science + Business Media B. V. 2012. Publikasi online pada 22 Juni 2012.

Coelho, F., Pereira, M.C., Cruz, Luí., Simoes, P., Barata, E. 2017. Affect and The Adoption of Pro-environmental Behaviour: A Structural Model. Journal of Environmental Psychology (doi: 10.1016/j.jenvp.2017.10.008.).

Coleman, J. S. 1993. Social Capital in The Creation of Human Capital. The American Journal of Sociology, Vol. 94 (95-120).

Corral-Verdugo, Victor, Jose Mireles-Acosta, Cesar Tapia-Fonllem dan Blanca FraijoSing. 2011. Happiness as Correlate of Sustainable Behavior: A Study of ProEcological, Frugal, Equitable and Altruistic Actions That Promote Subjective Wellbeing. Human Ecology ReviewVol. 18 No. 2. Society for Human Ecology.

Diener, E., Christie Napa Scollon dan Richard E. Lucas. 2003. The Evolving Concept of Subjective Well-Being: The Multifaceted Nature of Happiness. Costa \& I. C. Siegler (Eds.). Advances in Cell Aging and Gerontology: Vol. 15 (187-220). Elsevier. Science Direct. Amsterdam

Di Tella, Rafael dan Robert MacCulloch. 2006. Some Uses of Happiness Data in Economics. Journal of Economic Perspectives 20: 25-46.

Easterlin, Richard. 1995. Will Raising The Incomes of All Increase The Happiness of All ?. Journal of Economic Behaviour and Organization 27, no. 1: 35-48.

Easterlin, Richard. 2001. Income and Happiness: Towards A Unified Theory. Economic Journal 111: 465-484.

Ekman, Paul. 1992. An Argument for Basic Emotions. Cognition and Emotion 6, hal. 169-200.

Emmons, R. A., dan C. M. Shelton. 2002. Gratitude and The Science of Positive Psychology. Dalam C. R. Snyder dan S. J. Lopez (Eds.) Handbook of Positive Psychology (hal. 459-471). Oxford University Press: New York.

Emmons, R. A. dan M. E. McCullough. 2003. Counting Blessings Versus Burdens : An Experimental Investigation of Gratitude and Subjective Well-being in Daily Life. Journal of Personality and Social Psychology, 84, 377-389.

Falk, Armin dan Markus Knell. 2004. Choosing The Joneses: Endogenous Goals and Reference Standards. Scandinavian Journal of Economics 106 No. 3: 417-435.

Frey, Bruno dan Alois Stutzer. 2000. Happiness, Economy and Institutions. Economic Journal 110 No. 446: 918-938.

Frey, Bruno S. dan Alois Stutzer. 2002. Happiness and Economics: How The Economy and Institutions Affect Well-Being. Princeton University Press: New Jersey.

Frey, Bruno S. 2008. Happiness A Revolution in Economics. The MIT Press Cambridge : London. 
Gde Bagus Brahma Putra dan I Ketut Sudibia. Faktor- Faktor Penentu ...

Gardner, Jonathan dan Andrew Oswald. 2001. Does Money Buy Happiness ? A Longitudinal Study Using Data on Windfalls. https://www.researchgate.net/publication/4892491

Gifford, Robert. 2014. Environmental Psychology Matters. The Annual Review of Psychology (doi: 10.1146/annurev-psych-010213-115048).

Gruber, Jonathan dan Sendhil Mullainathan. 2005. Do Cigarette Taxes Make Smokers Happier?. Advances in Economic Analysis and Policy 5 No. 1: 1-43.

Harraka, M. 2002. Bowling Alone: The Collapse and Revival of American Community by Robert D. Putnam. Journal of Catholic Education, 6 (2). http://dx.doi.org/10.15365/joce.0602122013.

Helliwell, John F. dan Robert D. Putnam. 2004. The Social Context of Well-Being. Phil Trans. Royal Society London B 359, 1435-1446. doi:10.1098/rstb.2004.1522.

Jensen, Bjarne Bruun. 2002. Knowledge, Action and Pro-Environmental Behaviour. Environmental Education Research (325-334).

Kaiser, Florian G. dan Mark Wilson. 2004. Goal-directed Conservation Behavior: The Specific Composition of A General Performance. Personality and Individual Differences 36 (1531-1544).

Kollmuss, Anja dan Julian Agyeman. 2002. Mind The Gap: Why Do People Act Environmentally and What Are The Barriers to Pro-Environmental Behavior?. Environmental Education Research (239-260) (doi : 10.1080/13504620220145401).

Kitayama, Shinobu. dan Hazel Rose Markus. 2000. The Pursuit of Happiness and The Realization of Sympathy: Cultural Patterns of Self, Social Relations and Wellbeing. Dalam Ed Diener and Eunkook M. Suh (Eds.) Cultural and Subjective Well-Being. The MIT Press: Cambridge.

Kitayama, Shinobu. 2002. Culture and Basic Psychological Processes - Toward a System View of Culture: Comment on Oyserman et. al., (2002). Psychological Bulletin 128, hal. 89-96.

Kitayama, Shinobu, Batja Mesquita dan Mayumi Karasawa. 2006. Cultural Affordances and Emotional Experience: Socially Engaging and Disengaging Emotions in Japan and the United States. Journal of Personality and Social Psychology Volume 91, No. 5, hal. 890 -903.

Knack, S. dan Philip Keefer. 1997. Does Social Capital Have An Economic Payoff? A Country Investigation. The Quarterly Journal of Economics, 112, hal. 12511288.

Martin, Mike W. 2012. Happiness and The Good Life. Oxford University Press: New York.

McCullough, Michael E., Shelley D. Kilpatrick, Robert A. Emmons, dan David B. Larson. 2001. Is Gratitude A Moral Affect?. Psycological Bulletin. Volume 127 (249-266).

Morling, Beth, Shinobu Kitayama dan Yuri Miyamoto. 2002. Cultural Practices Emphasize Influence in The United States and Adjustment in Japan. Personality and Social Psychology Bulletin 28, hal. 311-323. 


\section{E-Jurnal Ekonomi dan Bisnis Universitas Udayana 8.1 (2019): 79-94}

Nettle, Daniel. 2005. Happiness: The Science Behind Your Smile. Oxford University Press: Oxford.

Neumark, David dan Andrew Postlewaite. 1998. Relative Income Concerns and The Rise in Married Women's Employment. Journal of Public Economics 70 No. 1: 157-183.

OECD. 2001. The Well-Being of Nations: The Role of Human and Social Capital. OECD Centre for Educational Research and Innovation: Paris.

Putnam, R. D., Robert Leonardi dan Raffaella Y. Nonetti. 1993. Making Democracy Work: Civic Traditions in Modern Italy. Princeton University Press.

Rubenson, Daniel. 2000. Participation and Politics: Social Capital, Civic Voluntarism, and Institutional Context. Paper Prepared for the ECPR Joint Sessions of Workshops, University of Copenhagen.

Sampson, R. J., Stephen W. Raudenbush, dan Felton Earls. 1997. Neighborhoods and Violent Crime: A Multilevel Study of Collective Efficacy. Science 277, hal. 918924.

Seedhouse, D. 1996. Health Promotion: Philosophy, Prejudice and Practice. Chichester, Wiley: UK.

Sivek, Daniel J. dan Harold Hungerford. 1990. Predictors of Responsible Behavior in Members of Three Wisconsin Conservation Organizations. The Journal of Environmental Education (35-40). Doi: 10.1080/00958964.1990.9941929.

Smith, Richard, Ed Diener, dan Douglas Wedell. 1989. Intrapersonal and Social Comparison Determinants of Happiness: A Range-Frequency Analysis. Journal of Personality and Social Psychology 56 No. 3: 317-325.

Stutzer, Alois dan Rafael Lalive. 2004. The Role of Social Work Norms in Job Searching and Subjective Well-Being. Journal of the European Economic Association 2: 696-719.

Todaro, Michael P. dan Stephen C. Smith. 2009. Pembangunan Ekonomi. Penerbit Erlangga: Jakarta.

Uchida, Yukiko, Vinai Norasakkunkit dan Shinobu Kitayama. 2004. Cultural Constructions of Happiness: Theory and Empirical Evidence. Journal of Happiness Studies 5, hal. 223 - 239.

Veblen, Thorstein. 1899. The Theory of Leisure Class. Modern Library.

Veenhoven, Ruut. 2006. How Do We Asess How Happy We Are ?: Tenets, Implications and Tenability of Three Theories. Paper Presented at Conference on 'New Directions in The Study of Happiness: United States and International Perspectives'. University of Notre Dame, USA, October 22-24.

Veenhoven, Ruut. 2015. Social Conditions For Human Happiness: A Review of Research. International Journal of Psychology 379 - 391. DOI: 10.1002/ ijop.12161.

White, Nicholas P. 2006. A Brief History of Happiness. Blackwell Publishing: USA.

Woolcock, M. 2001. The Place of Social Capital in Understanding Social and Economic Outcomes. Dalam Proceeding OECD/HRDC Conference, Quebec, 19-21 March 2000: The Contribution of Human and Social Capital to Sustained 
Gde Bagus Brahma Putra dan I Ketut Sudibia. Faktor- Faktor Penentu ...

Economic Growth and Well-Being (ed. J. F. Helliwell), hal. 65-88. HDRC: Ottawa.

World Happiness Report. 2017. Helliwell, John F., Haifang Huang dan Shun Wang (ed). United Nations.

Zautra, Alex J., Glenn G. Affleck, Howard Tennen, John W. Reich, dan Mary C. Davis. 2005. Dynamic Approaches to Emotions and Stress in Everyday Life: Bolger and Zuckerman Reloaded with Positive as Well as Negative Affects. J Pers. (doi:10.1111/j.0022-3506.2005.00357.x.). 